\title{
Hinge-line migration of Petermann Gletscher, north Greenland, detected using satellite-radar interferometry
}

\author{
ERIC Rignot \\ Jet Propulsion Laboratory, California Institute of Technology, Pasadena, California 91109, U.S.A.
}

\begin{abstract}
The synthetic-aperture radar-interferometry technique is used to detect the migration of the limit of tidal flexing, or hinge line, of the floating ice tongue of Petermann Gletscher, a major outlet glacier of north Greenland. The hinge line is detected automatically from differential interferograms using a model-fitting technique based on an elastic-beam theory. The statistical noise of the model fit is less than $3 \mathrm{~mm}$, and the hinge line is mapped with a precision of $30 \mathrm{~m}$. Following automatic registration of multidate image data to a precision of $5 \mathrm{~m}$, hinge-line migration is subsequently detected with a precision of $40 \mathrm{~m}$ in the horizontal plane across the glacier width. The results show that the hinge line of Petermann Gletscher migrates back and forth with tide by $\pm 70 \mathrm{~m}$, in excellent agreement with the migration calculated from ocean tides predicted by a tidal model combined with the glacier surface and basal slope measured by an ice-sounding radar. Superimposed on the short-term hinge-line migration due to tide, we detect a hinge-line retreat of $270 \mathrm{~m}$ in 3.87 years which varies across the glacier width by $\pm 120 \mathrm{~m}$. The retreat suggests glacier thinning at a rate of $78 \pm 35 \mathrm{~cm}^{\text {ice a }}{ }^{-1}$. Coincidentally, an analysis of ice-volume fluxes indicates that the hinge-line ice flux of Petermann Gletscher exceeds its balance flux by $0.88 \pm 1 \mathrm{~km}^{3}$ ice $\mathrm{a}^{1}$, which in turn implies glacier thinning at $83 \pm 95 \mathrm{~cm}$ ice $\mathrm{a}^{-1}$ in the glacier lower reaches. Both methods therefore suggest that Petermann Gletscher is currently losing mass to the ocean.
\end{abstract}

\section{INTRODUCTION}

The transition region between the grounded part of an ice sheet and its floating part, often referred to as the grounding line, is fundamental to the stability of an ice sheet (Weertman, 1974; Hughes, 1977; Thomas and Bentley, 1978). Because the glacier slopes are typically small at the grounding line, the horizontal position of the grounding line is sensitive to changes in ice thickness, sea level or elevation of the sea bed (Hughes, 1977; Thomas, 1979).

Locating a glacier grounding line in the field, or using remote-sensing techniques, remains a challenging exercise (e.g. Vaughan, 1994). As a result, the grounding lines of Antarctic and Greenland glaciers are known only with considerable uncertainty.

Synthetic-aperture radar interferometry is a new technique for measuring glacier displacements from space at the millimeter level over a period of just a few days (Goldstein and others, 1993). Over floating tongues and ice shelves, the measured glacier displacement is a combination of creep flow and tidal motion which can be separated using differential (multiple) interferograms (Hartl and others, 1994). With differential interferometry, the limit of tidal flexing of the glacier, or hinge line, may be measured at an unprecedented level of spatial detail and accuracy, simultaneously across the entire glacier width, with a uniform sampling scheme, over large areas (Rignot, 1996, 1998; Rignot and others, 1997).

Satellite-radar interferometry is used here to refine our earlier mapping of the hinge line of Petermann Gletscher (Rignot, 1996), a major outlet glacier of north Greenland, and detect its hinge-line migration over a 4 year time period. The radar data were collected by the European Space Agency (ESA)'s Earth Remote Sensing Satellites (ERS-1 and ERS-2) instruments. The mapping of the hinge line is repeated at different epochs and at different tidal phases to separate the effect of short-term variations in sea level (associated with ocean tide) from that of longer-term changes in glacier thickness which we seck to estimate. We analyze the errors associated with the mapping of the hinge line and the detection of hinge-line migration. The inferred change in glacier thickness is subsequently compared to an analysis of ice-volume fluxes to provide complementary information on the current state of the mass balance of Petermann Gletscher.

\section{STUDY AREA}

Petermann Gletscher, located at $81^{\circ} \mathrm{N}$ and $60^{\circ} \mathrm{W}$ on the northwestern flank of the Greenland ice sheet, is named after the German geographer Dr A. Petermann (Koch, 1928). Petermann Fjord was discovered on 27 August 1871 during Hall's U.S. Steamer Polaris expedition (Bessels, 1876) but it was not untilJune 1876 that Coppinger and Fulford realized that the fjord was filled with a glacier. In 1892, Peary discovered that the glacier reached far into the "Inlandsis" (Koch, 1940).

Petermann Gletscher is one of the longest glaciers in the Northern Hemisphere. It develops an extensive floating tongue $(70 \mathrm{~km} \mathrm{long})$, with a terminus only a few meters above sea level. In 1917, Koch (1928) noted that the outermost part of the glacier beyond a line drawn between Cape Agnes (where Porsild Gletscher meets with Petermann Gletscher) 
and Cape Coppinger was afloat, with a smooth surface free from crevasses (Fig. 1). The glacier grounding line is more or less in the same position today (Rignot, 1996). Historical photographs also suggest that little change in the glacier ice-front position occurred in the past 50 years (Higgins, 1991).

Although the historical record is suggestive of glacier stability, Petermann Gletscher is far from being a sluggish glacier (Weidick, 1995). It flows at more than $1 \mathrm{~km} \mathrm{a}^{-1}$ into the Arctic Ocean (Higgins, 1991), faster than any other glacier in north Greenland, and is the largest discharger of ice in north Greenland (Rignot and others, 1997). Like most other northern outlet glaciers, Petermann Gletscher loses mass to the ocean mostly through basal melting of its floating tongue (Rignot, 1996). Yet, nowhere in the north and northeast sectors of Greenland are the inferred basal-melt rates higher than on Petermann Gletscher (Rignot and others, 1997). How the glacier can maintain its mass balance while at the same time flowing rapidly to the ocean and sustaining massive removal of ice from basal melting remains unclear.

\section{METHODS}

\section{Interferogram generation}

The details of the method used to generate radar interferograms of Petermann Gletscher have been described by
Rignot (1996). In brief, we combine two passages of the ERS satellite coherently to form a radar interferogram, which is then corrected for surface topography using a prior-determined precision digital elevation model (DEM) of north Greenland assembled by Ekholm (1996). DEM control points are used to refine the initial estimates of the orbit separation between the successive passages of the satellite (the so-called interferometric baselines) obtained from the ERS precise orbit data distributed by the German Archive and Processing Facility (DPAF).

Two topography-corrected interferograms spanning the same time interval are then differenced to yield a difference interferogram which measures only the tidal displacement of the glacier. We refer to this difference interferogram as a "tide interferogram" in the rest of the paper. The success of differencing relies on the assumption that the glacier creep flow remains steady and continuous during the period of observation so that the displacement signal associated with creep remains the same in both topography-corrected interferograms and thereby cancels out when computing their difference. When this assumption is invalid, motion fringes are detected on grounded ice, as for instance in the case of the mini-surge of Ryder Gletscher (Joughin and others, 1996).

The list of the ERS data used in this study is given in Table 1, along with tides predicted at the time of passage of the satellite. The 1992 interferograms combined ERS-1 data acquired along the same orbit every 3 days. The 1996 inter-

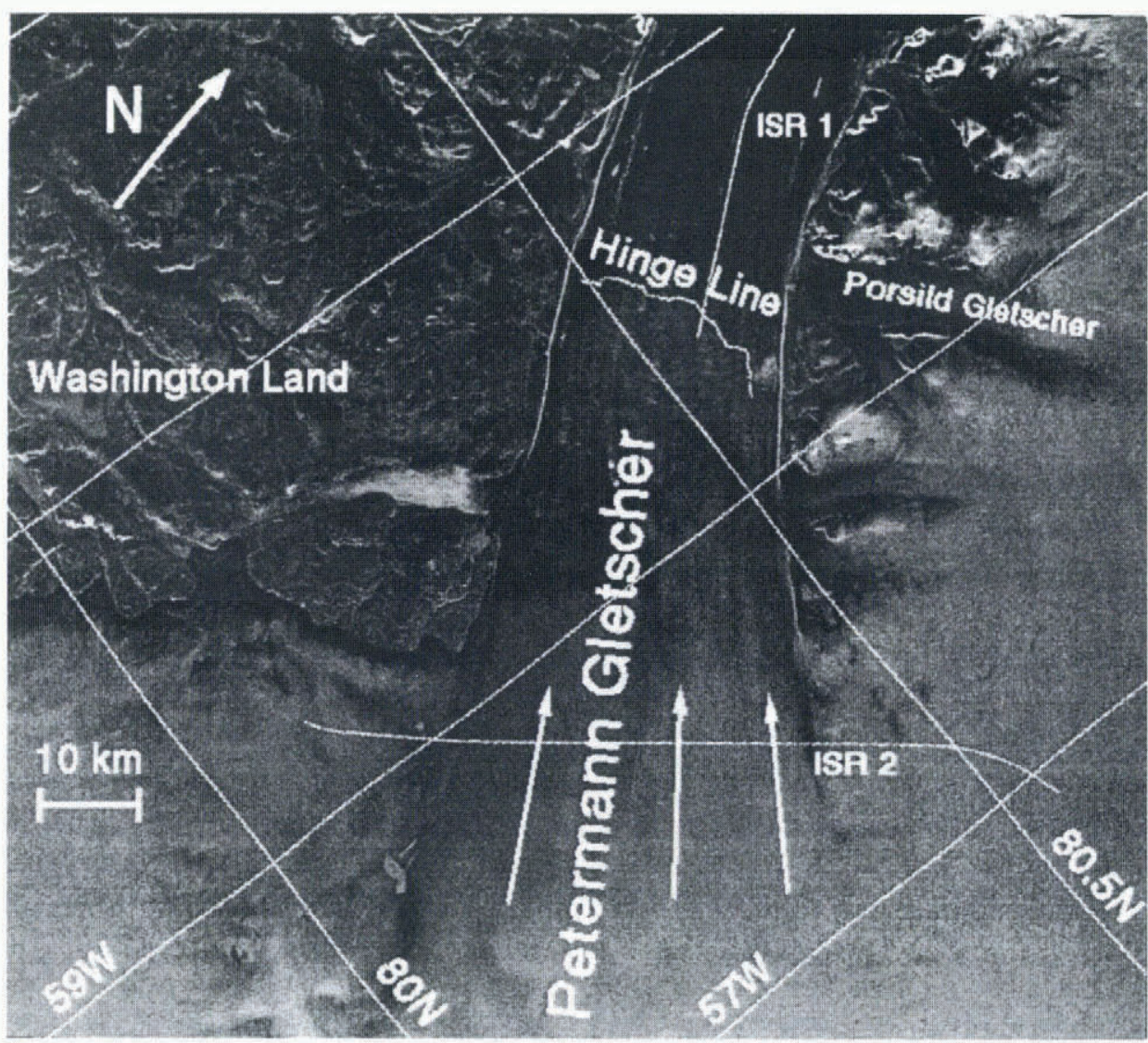

Fig. 1. Radar amplitude image $(140 \times 104 \mathrm{~km})$, in a polar stereographic projection $(50 \mathrm{~m}$ sample spacing) of Petermann Gletscher, north Greenland, acquired by ERS-1 on 31 December 1995. The glacier flows to the north along the eastern flank of Washington Land. ISRI denotes the ice-sounding radar data collected along the main ice flow (Allen and others, 1997) (Fig. 5). ISR2 denotes the ISR data collected in the transverse direction, approximately at the equilibrium-line altitude (ELA) of the glacier. The hinge-line profile inferred from the ERS interferometric data is shown as a thin white line, west of Porsild Gletscher. ERS was flying from right to left in the figure, illuminating from the bottom (descending, right-looking pass). ( C) ESA 1995.) 
Table 1. ERS data used in this study and tides predicted at the time of passage of the satellite using the FES.95.2 Grenoble ocean-tidal model (Le Provost and others, 1998) at $81.5^{\circ} \mathcal{N}$, 63 E. In 1995-96, ERS-1 and ERS-2 images acquired 1 day apart were combined to form interferograms. El 22373 was combined with E2 2700, E1 23876 with E2 4203, E1 23332 with E2 3659 and E1 23833 with E2 4160. In 1992, ERS-1 images acquired 3 days apart were combined to form interferograms. E1 2947 was combined with E2 2904, E1 2947 with E1 2990, E1 3248 with E1 3205 and E1 3248 with E1 3291

\begin{tabular}{ccr}
\hline $\begin{array}{c}\text { ERS orbit frame } \\
\text { E1 }=\text { ERS-1, E2 = ERS-2 }\end{array}$ & $\begin{array}{c}\text { Date } \\
\text { mm-day-year }\end{array}$ & $\begin{array}{r}\text { Tide } \\
\mathrm{cm}\end{array}$ \\
\hline E1 2904-1953 & $04-02-92$ & 73.3 \\
E1 2947-1953 & $07-02-92$ & 52.0 \\
E1 2990-1953 & $10-02-92$ & 4.2 \\
E1 3205-1953 & $25-02-92$ & -11.5 \\
E1 3248-1953 & $28-02-92$ & 7.6 \\
E1 3291-1953 & $02-03-92$ & 52.2 \\
E1 22373-1953 & $25-10-95$ & 90.2 \\
E2 2700-1953 & $26-10-95$ & 86.5 \\
E1 23876-1953 & $07-02-96$ & 63.8 \\
E2 4203-1953 & $08-02-96$ & 49.9 \\
E1 23332-1953 & $31-12-95$ & -10.3 \\
E2 3659-1953 & $01-01-96$ & 7.5 \\
E1 23833-1953 & $04-02-96$ & 71.4 \\
E2 4160-1953 & $05-02-96$ & \\
\hline
\end{tabular}

ferograms combined data acquired by ERS-1 and ERS-2 every 35 days but with ERS-2 following ERS-1 by 1 day.

\section{Comparison of image products}

To compare tide interferograms acquired at different epochs and along slightly different orbits, the interferograms are projected on to a common Earth-fixed grid, here a polar stereographic (PS) grid, with a secant plane at $70^{\circ} \mathrm{N}$, and a $50 \mathrm{~m}$ sample spacing (Fig. 1). The actual spatial resolution of the ERS data is $20 \mathrm{~m}$ on the ground in the cross-track (or range) direction and $4 \mathrm{~m}$ in the along track (or azimuth direction).

The automatic projection and regridding of the ERS data is not of sufficient precision to guarantee that the gridded image data overlap perfectly on top of each other due to uncertainties in absolute positioning of the satellite. To estimate the residual offsets between multi-date images, we calculate the cross-correlation peak of the radar signal intensity between a reference radar scene and the other scenes. Cross-correlation of the signal intensity is calculated over non-moving parts of the scene, here the mountainous regions bordering Petermann Fjord. The retrieved image offsets are fitted through a plane, which is then used to resample the different scenes to the reference scene. The goodness of fit of the plane fitting, which measures the precision of registration of the data, is $5 \mathrm{~m}$ in the case of Petermann Gletscher.

The registered tide interferograms, centered at the hinge line of Petermann Gletscher, are shown in Figure 2. The hinge line is located at the inward limit of the zone of tidal flexing or flexure zone of the glacier. The flexure zone is a region about $4-6 \mathrm{~km}$ in length, characterized by a high fringe rate in Figure 2, where the glacier ice adjusts rapidly to hydrostatic equilibrium as it reaches the ocean.

\section{Systematic mapping of the hinge line}

In a prior study of Petermann Gletscher, the glacier hinge line was mapped by locating the minimum of one-dimensional tidal profiles successively across the entire glacier width (Rignot, 1996). While this earlier procedure was sufficient to locate the position of the hinge line for mass-flux calculations, it is not optimal for change-detection applications. Here, we improve upon the mapping precision of the hinge line by using a model-fitting technique. Instead of using a few points to locate the hinge line, the method uses entire profiles and is thus more robust to noise.

The glacier floating tongue is represented as a thin elastic beam of ice, of unlimited length, clamped solidly at one end on bedrock (at the hinge line), freely floating on sea water along its base and unconstrained along its sides. Let $x$ denote the beam horizontal axis oriented perpendicular to the glacier hinge line. The solution of the differential equation describing the vertical displacement of the beam in response to tide has been discussed by Holdsworth (1969, 1977). The beam vertical displacement, $w(x)$, along the $x$ axis may be written as

$$
\begin{aligned}
w(x)= & \frac{w_{\max }-w_{\min }}{1+e^{-\pi}}\left[1-e^{-\beta\left(x-x_{\mathrm{H}}\right)}\left(\cos \beta\left(x-x_{\mathrm{H}}\right)\right.\right. \\
& \left.\left.+\sin \beta\left(x-x_{\mathrm{H}}\right)\right)\right], \quad x>x_{\mathrm{H}} \\
w(x)= & w_{\min }, \quad x<x_{\mathrm{H}}
\end{aligned}
$$

where $w_{\max }$ and $w_{\min }$ represent, respectively, the maximum and minimum vertical displacement of the beam along the $x$ axis, $\beta$ is a damping factor describing the decay length of the beam displacement along the $x$ axis, and $x_{\mathrm{H}}$ is the hinge-line position along the $x$ axis.

The elastic-beam model described in Equation (1) is applied to tidal profiles extracted across the entire glacier width, in a direction perpendicular to the iso-contours of vertical displacement of the glacier tongue represented by the interferometric fringes displayed in Figure 2. For each tidal profile, we estimate four parameters of Equation (1) in the least-square sense: the damping factor, $\beta$, the maximum and minimum height of the profile, $w_{\max }$ and $w_{\min }$, and the hinge-line position, $x_{\mathrm{H}}$. The parameter of importance is $x_{\mathrm{H}}$, since it defines the hinge-line position along each profile. The damping factor, $\beta$, is expected to vary slightly across the glacier width due to changes in ice thickness. The minimum displacement, $w_{\min }$, in principle close to zero, is a free parameter which accounts for the presence of phase noise over grounded ice (meaning the interferometric phase is not identically zero over grounded ice in the tidal interferograms). A measure of the goodness of fit is provided by the rms difference between the model fit and the interferometric data.

An example of model fitting is shown in Figure $3 a$ and $b$. Over the more than 1000 profiles analyzed in this study, the goodness of fit averages $3 \pm 1 \mathrm{~mm}$. At this level of precision, one can hardly notice the difference between model fit and real data (Fig. 3b), which illustrates both the low noise level of the data and the relevance of the elastic-beam model.

Model fitting is less reliable along the glacier side margins. In that region, the glacier tidal displacement is the result of complex interactions between the hinge line of Petermann Gletscher, the glacier side margins and the hinge line of Porsild Gletscher (Figs 1 and 2). A consequence of this interaction is a "pinching" of the zone of tidal flexure along the side margins that cannot be accounted for by our 


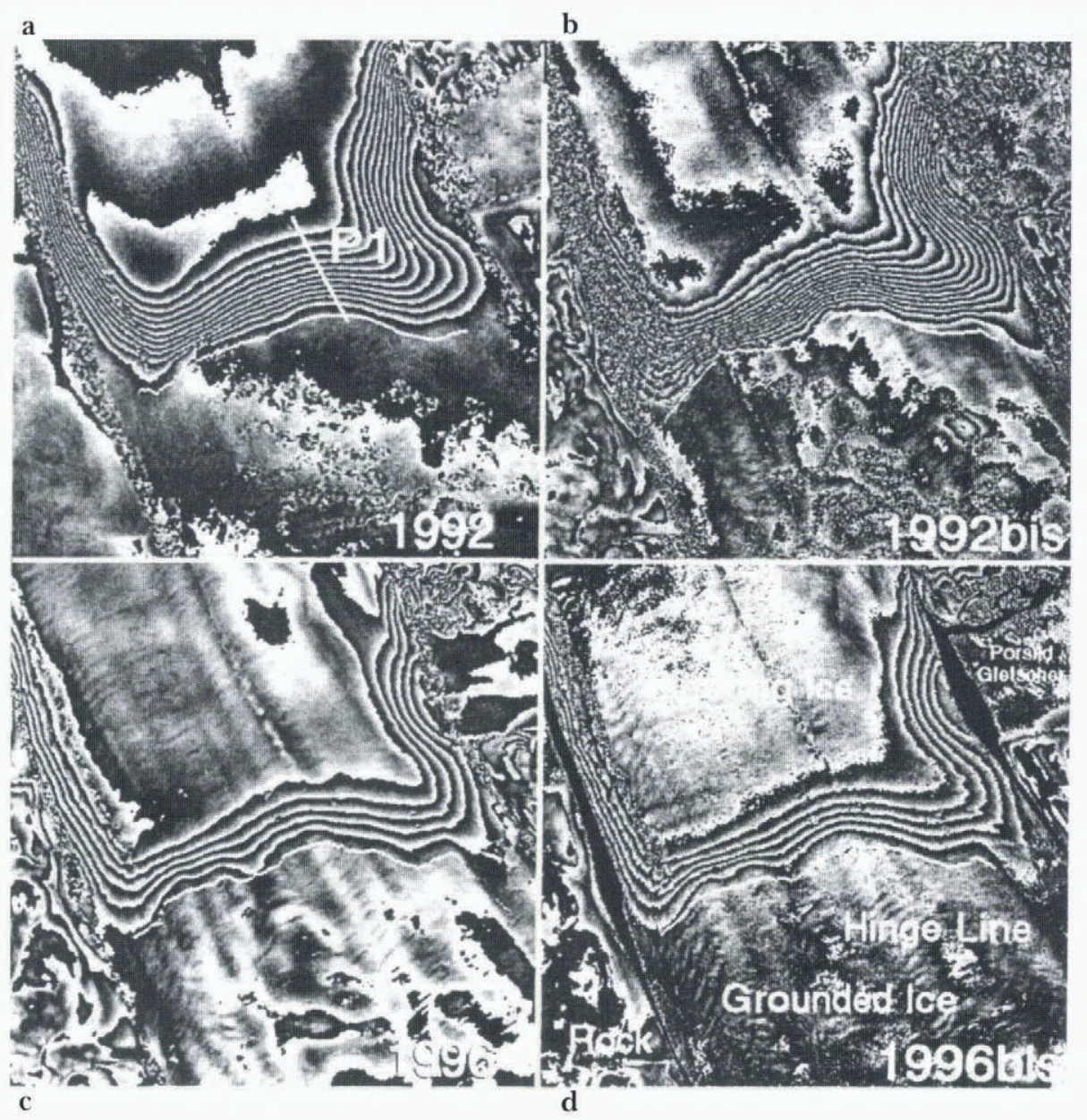

Fig. 2. Tidal displacement and hinge-line position of Petermann Gletscher measured from ERS radar interferometry in (a) 1992 (E1 3205-E1 3248-E1 3291 in Tables 1 and 2); (b) 1992bis (E1 2904-E1 2947-E1 2990 in Tables 1 and 2); (c) 1996 (E123332-E2 3659-E1 23833-E2 4160 in Tables 1 and 2) and (d) 1996bis (E1 22373-E22700-E1 $23876-E 24203$ in Tables 1 and 2). Each fringe or full cycle of grey-tone variation represents a $28 \mathrm{~mm}$ differential displacement of the glacier tongue along the radar line of sight, equivalent to a $31 \mathrm{~mm}$ vertical displacement of the glacier tongue induced by changes in ocean tide. The location of profile P1 in Figure 3 is indicated in the upper left quadrant (white thick line), interferogram 1992 and is parallel to the ISRI profile shown in Figure 1.

simple one-dimensional elastic-beam model. As a result, the rms error of the model fit is higher along the side margins compared to the glacier center and the inferred value of $\beta$ deviates substantially for that retrieved along the glacier center.

To estimate the mapping precision of the hinge-line position shown in Figure 2 and plotted in Figure 4, we smooth the inferred positions using a square box averaging filter about one ice thickness in width (or $600 \mathrm{~m}$ ) and compare the smoothed curve to the original one. The result is a $30 \mathrm{~m}$ rms difference between the two curves. If we assume that variations in hinge-line position occurring over a length scale of less than one ice thickness are due to noise, this result means that $\pm 30 \mathrm{~m}$ represents the statistical noise of our relative determination of the hinge-line position at one epoch.

Using the same box filter, we estimate the precision of detecting hinge-line migration. We assume that any deviation in hinge-line migration from its mean value calculated within a square box about one ice thickness in width is due to noise. Comparing various hinge-line positions, we find a rms noise of $40 \mathrm{~m}$. This value is consistent with the $30 \mathrm{~m}$ precision in hinge-line mapping for individual interferograms, combined with the $5 \mathrm{~m}$ precision in registration of independent tidal profiles.

Hence, the relative precision with which hinge-line mi- gration is detected in the case of Petermann Gletscher is $40 \mathrm{~m}$. In the absence of ground-control points of known latitude and longitude, the absolute precision with which we know the hinge-line position is in comparison probably no better than $100 \mathrm{~m}$. In effect, the ERS data are registered to a DEM of north Greenland at a $500 \mathrm{~m}$ sample spacing (Ekholm, 1996) with a precision no better than \pm 0.1 sample spacing or $\pm 50 \mathrm{~m}$. This is a limitation of the satellite-radar technique compared for instance to Global Positioning System (GPS) surveys which are capable of locating points on the ground to within 5-10 m. It is, however, important to note that the uncertainty in absolute location of the radar data has no influence on the precision of detecting hingeline migration. As long as it is possible to cross-correlate common fixed-image features between multi-date image data, the radar data alone are sufficient to detect hinge-line migration with great precision.

No ground measurements of the hinge-line position are available on Petermann Gletscher to compare with our results. Laser-altimetry data and ice-sounding radar data can locate the hinge line of Petermann Gletscher within a few hundred meters to a kilometer at best. No GPS data have been collected on Petermann Gletscher. Yet, GPS data collected on Rutford Ice Stream, Antarctica, exhibit a rms noise one order of magnitude larger $(\mathrm{cm})$ than that 

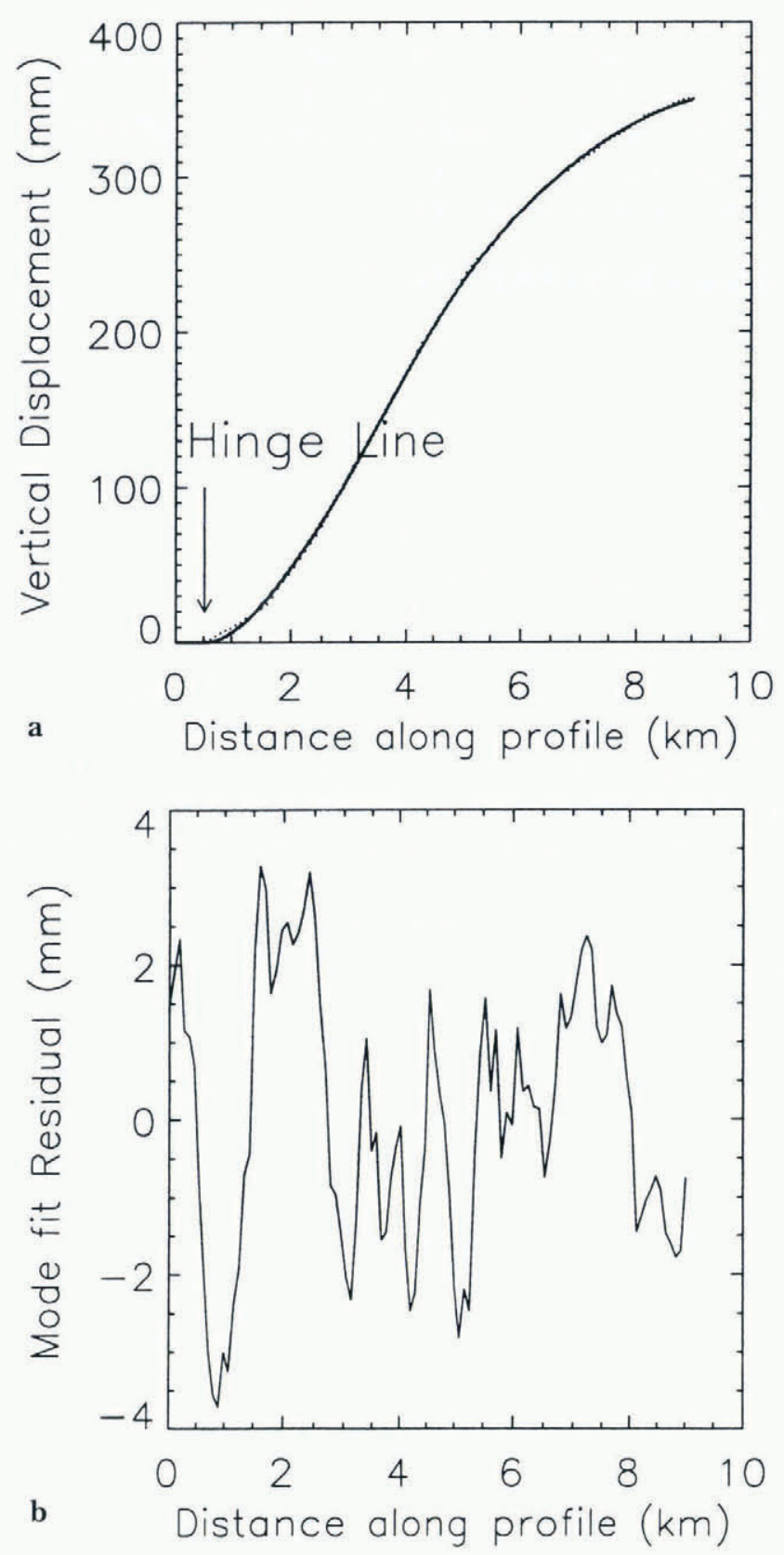

Fig. 3. (a) Tidal profile P1 (Fig. 2) measured interferometrically by ERS (dots) and model fit from an elastic-beam theory (solid line) and $(b)$ difference between the model fit and the ERS data. The rms error of the model fit is $1.7 \mathrm{~mm}$. The inferred damping factor of the ice is $\beta=0.3 \mathrm{~km}^{-1}$. The inferred hinge-line position is indicated by an arrow in panel $(a)$.

achieved with ERS radar interferometry $(\mathrm{mm})$ over the same area (Rignot, 1998), meaning that the hinge-line position may only be mapped with a precision of $100-200 \mathrm{~m}$ with GPS (Vaughan, 1994) compared to $40 \mathrm{~m}$ with satelliteradar interferometry. Simply stated, the precision of hingeline mapping achieved with radar interferometry is totally unprecedented.

\section{RESULTS}

\section{Hinge-line migration}

Four independent mappings of the hinge line of Petermann Gletscher are shown in Figure 4. Two main features are identified from the inferred profiles: (1) the hinge line migrates back and forth on a short-term (days to months)
Petermann Gletscher

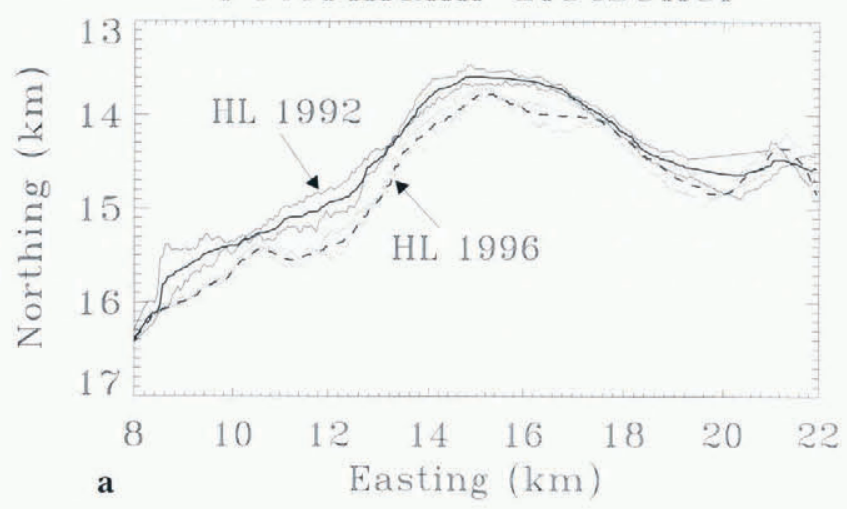

1992 to 1996 retreat

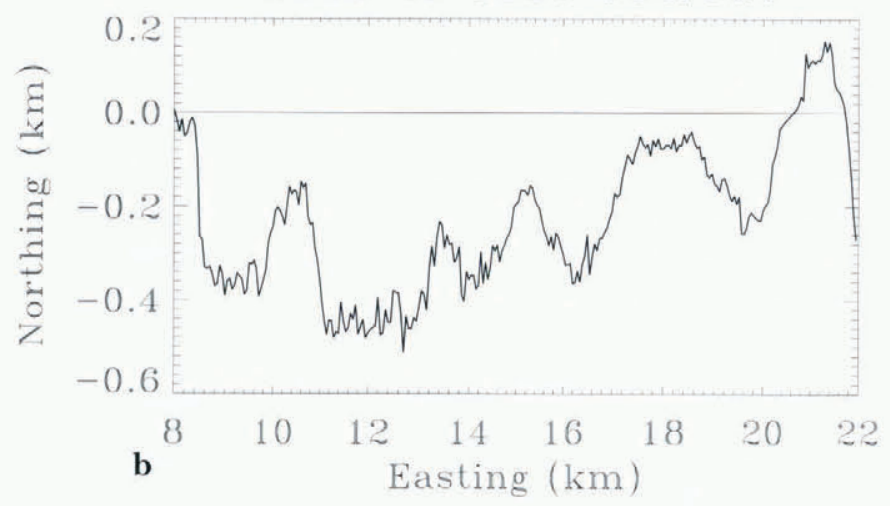

Fig. 4. Hinge-line position of Petermann Gletscher at four different epochs( Tables 1 and 2) inferred from model fitting of tidal profiles (Fig. 2). (a) Hinge-line position in 1992 and 1992bis (thin black lines), average position in 1992 (thick black line), position in 1996 and 1996bis (thin grey lines) and average position in 1996 (thick grey line). (b) Hinge-line retreat between the 1992 mean position and the 1996 mean position.

basis in both 1992 and 1996, which we interpret as a change in ocean tide; (2) the hinge line retreats several hundred meters between 1992 and 1996, which we interpret as a change in glacier thickness.

The hinge-line migration across the glacier width (calculated excluding a region about $250 \mathrm{~m}$ wide along the side margins where hinge-line mapping is less precise) is $78 \pm 213 \mathrm{~m}$ between the two 1992 interferograms and $42 \pm 162 \mathrm{~m}$ between the two 1996 interferograms (where \pm denotes the value of the standard deviation of the difference). The mean value of the migration is therefore above the $40 \mathrm{~m}$ precision level of detection of hinge-line migration discussed earlier and so is its standard deviation. This means that the hinge-line migration is real and that it is also spatially varying across the glacier width.

The reality of the hinge-line migration detected between the two 1992 interferograms and the two 1996 interferograms is discussed in more detail in the next section where we show that the measured migration is in good agreement with that predicted from ocean tides. The reality of the spatial variation in hinge-line migration across the glacier width indicates that the transition from grounded to floating ice is not a well-defined grounding line, but rather a "grounding zone", which extends up to a couple of hundred meters in some areas and only a few tens of meters in others. Presumably, the width of the grounding zone varies as a result of spatial variations in surface and basal slope.

The hinge-line retreat measured between 1992 and 1996 
using four positions of the hinge line varies from a lower value of $212 \pm 230 \mathrm{~m}$ for interferogram 1992 minus interferogram 1996bis (Figs 2 and 4) to a maximum value of $333 \pm 127 \mathrm{~m}$ for interferogram 1992bis minus interferogram 1996. The retreat measured comparing the mean 1992 and 1996 positions (thick curves in Figure 4) is $272 \pm 120 \mathrm{~m}$. The retreat is well above the noise level of detection $(40 \mathrm{~m})$ and above the level of migration associated with tide. We attribute the 4 year hinge-line retreat to glacier thinning.

\section{Glacier thinning}

The glacier slope of Petermann Gletscher at the hinge line may be calculated from the glacier-elevation profile collected by the NASA/Wallops airborne laser altimeter (Krabill and others, 1995) combined with ice-thickness data also collected in 1995 by the University of Kansas' icesounding radar (ISR) (Allen and others, 1997). The surface slope along the profile which follows the glacier center line is $1 \%$ at the hinge line. The inferred basal slope is also $1 \%$ (Fig. 5). The KMS DEM confirms that the glacier surface slope is $1 \%$ in that region.

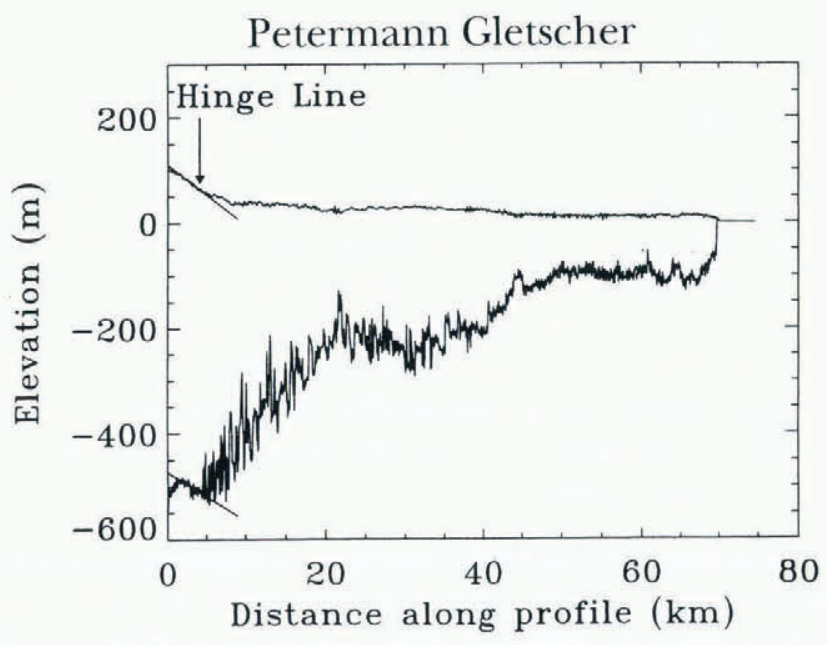

Fig. 5. Thickness profile of Petermann Gletscher, north Greenland, obtained from 1995 laser altimetry data for the surface (Krabill and others, 1995) and ice-sounding radar data for the thickness (Allen and others, 1997). The precision in surface elevation is $10 \mathrm{~cm}$. Ice thickness is known with $10 \mathrm{~m}$ uncertainty. The hinge-line position inferred from radarinterferometry data in late 1995 is indicated by an arrow. The grounding line and the line of first hydrostatic equilibrium of the ice are 1-2 km below the hinge line (Rignot and others, 1997). The glacier surface and basal slopes, noted respectively $\alpha_{\mathrm{s}}$ and $\alpha_{\mathrm{b}}$ in the text and shown by $10 \mathrm{~km}$ long solid line fits in the figure, and are both equal to $-1 \pm 0.1 \%$.

The change in ice thickness, $\delta h$, produced by a grounding-line migration, $\delta x_{\mathrm{H}}$ (here assumed to be equal to the hinge-line migration), was derived by Thomas and Bentley (1978). We re-write their expression as

$$
\delta h=\delta x_{\mathrm{H}}\left[\left(1-\frac{\rho_{\mathrm{w}}}{\rho_{\mathrm{i}}}\right) \alpha_{\mathrm{b}}-\alpha_{\mathrm{s}}\right]
$$

where $\rho_{\mathrm{w}}$ is the density of sea water, $\rho_{\mathrm{i}}$ is the column-averaged density of ice, $\alpha_{\mathrm{b}}$ is the basal slope counted positive upwards and $\alpha_{\mathrm{s}}$ is the surface slope also counted positive upwards. Thinning corresponds to $\delta h<0$ and retreat corresponds to $\delta x<0$.
Using $\rho_{\mathrm{w}}=1030 \mathrm{~kg} \mathrm{~m}^{-3}, \rho_{\mathrm{i}}=917 \mathrm{~kg} \mathrm{~m}^{-3}$ and $\alpha_{\mathrm{s}}=\alpha_{\mathrm{b}}=$ -0.01 , we find that a hinge-line migration of $\delta x_{\mathrm{H}}$ of $-272 \pm 120 \mathrm{~m}$ in 3.87 years (mean time difference between the 1992 data and the 1996 data according to Table 1) corresponds to a change in glacier thickness $\delta h$ of $-78 \pm 35 \mathrm{~cm}$ ice $\mathrm{a}^{-1}$, meaning ice thinning.

\section{Comparison with predicted tides}

Tidal predictions at the time of passage of the ERS satellites were made using the Grenoble finite-element ocean-tide model FES.95.2, which predicts through hydrodynamic modeling and altimeter-data assimilation the eight major tidal constituents on a complex finite-element grid of variable resolution, ranging from $200 \mathrm{~km}$ in the deep ocean to $10 \mathrm{~km}$ along the coastlines. The solutions have been widely distributed on a $0.5 \times 0.5$ degree grid for convenience (Le Provost and others, 1998).

For verification of the model, we compared the four major constituents (M2, K1, Ol and S2) predicted at Thank God Harbor (north of the Petermann Gletscher front) to those measured by the U.S. Polaris expedition in 1871 (Bessels, 1876). The root-mean-square error of the predicted constituents is $1.7 \mathrm{~cm}$, which is consistent with the estimated global precision of $2.8 \mathrm{~cm}$ derived by Le Provost and others (1998) for the FES.95.2 model. Hence, the ocean tides predicted by the tide model are accurate to within a few centimeters.

The predicted tides for Petermann Gletscher $\left(81.5^{\circ} \mathrm{N}\right.$, $\left.63^{\circ} \mathrm{W}\right)$ at the time of passage of the ERS satellite are listed in Table 1. Comparison of these data with the tidal displacements measured in the ERS tide interferograms is shown in Table 2. The difference between predicted tide differences and those measured by ERS is $1.5 \mathrm{~cm}$ on average with a $3.6 \mathrm{~cm}$ standard deviation. The agreement between model predictions and measured tides is remarkable given that the model solution does not include the detailed geometric characteristics of Petermann Fjord and is made for an area $80 \mathrm{~km}$ north of the hinge line, at the mouth of Petermann Fjord in Hall Basin. The result confirms both the relevance of the tidal model and the precision of the interferometric measurements of tidal differences.

Table 2. Tidal differences measured by ERS compared with tidal differences predicted by the Grenoble FES.95.2 oceantidal model ( Table 1). Interferogram 1996bis is the difference between pair E1 22373-E2 2700 and pair E1 23876E24203. Its predicted tidal difference is $(90.2-86.5)$ $(63.8-49.9)=-10.2 \mathrm{~cm}$. Interferogram 1996 is the difference between pair E1 23332-E2 3659 and pair E1 23833-E2 4160. Interferogram 1992 is the difference between pair E1 3248-E13205 and E1 3291-E1 3248. Interferogram 1992bis is the difference between pair E1 2947-E1 2904 and pair E1 2990-E1 2947. Its tidal difference is calculated as $(7.6+11.5)+(7.6-52.2)=-2.5 .5 \mathrm{~cm}$

\begin{tabular}{ccc}
\hline $\begin{array}{c}\text { ERS-l tide } \\
\text { interferogram }\end{array}$ & $\begin{array}{c}\text { Tidal difference } \\
\text { measured }\end{array}$ & $\begin{array}{c}\text { Tidal difference } \\
\text { predicted }\end{array}$ \\
& $\mathrm{cm}$ & $\mathrm{cm}$ \\
\hline 1996 & -12.9 & -10.2 \\
1996bis & -10.3 & -14.9 \\
$1992 \mathrm{bis}$ & +30.9 & +26.5 \\
1992 & -25.8 & -25.5 \\
\hline
\end{tabular}


Tide predictions are useful for interpreting the interferometric measurements. Radar interferometry only measures differences in tidal displacement and hence does not provide any information on absolute tide. As the tide changes, the glacier hinge line is expected to migrate back and forth to maintain hydrostatic equilibrium, usually retreating when the tide is high and advancing when the tide is low. If the tidal amplitude and the glacier slopes are known, the bias in hinge-line position induced by tide can be estimated to deduce the mean sea-level hinge-line position.

Using the calculated tidal differences in Table 2 and a $1 \%$ glacier slope, we predict that the 1992 hinge-line position should migrate $50 \mathrm{~m}$ between the two 1992 tide interferograms vs $78 \mathrm{~m}$ measured (the sign of the migration is correctly predicted). Similarly, the hinge-line migration should migrate $5 \mathrm{~m}$ between the two 1996 tide interferograms vs $42 \mathrm{~m}$ measured. The differences between calculated and real migration are within the noise level of the hinge-line migration detection $(40 \mathrm{~m})$. We conclude that short-term variations in hinge-line position are due to changes in ocean tide.

\section{Analysis of mass fluxes}

The hinge-line flux of Petermann Gletscher is $12.0 \pm 0.5 \mathrm{~km}^{3}$ ice a ${ }^{1}$ (Rignot, 1996). We now compare this result to the balance flux calculated from the glacier accumulation and ablation above the hinge line. To calculate surface ablation, we use Reeh's (1991) degree-day model, following the implementation of Huybrecht and others (1991). A degree-day factor of $9.8 \mathrm{~mm} \mathrm{deg}^{-1} \mathrm{~d}^{-1}$ is used since this is the median value measured in north Greenland by past experiments (9.6 $\mathrm{mm} \mathrm{deg}^{-1} \mathrm{~d}^{-1}$ on Storstrømmen Gletscher in the northeast measured by Boggild and others (1994), 9.8 and $5.9 \mathrm{~mm} \mathrm{deg}^{-1} \mathrm{~d}^{-1}$ measured by Braithwaite and others (1998a, b) and Konzelmann and Braithwaite (1995) at two sites near the Hans Tausen ice cap in north Greenland). The degree-day factor of $8 \mathrm{~mm} \mathrm{deg}^{-1} \mathrm{~d}^{-1}$ commonly used by ice-sheet modellers in the remainder of Greenland, and which is based on studies conducted at lower latitudes along the west coast, underpredicts ablation in the north, as pointed out by Braithwaite (1995). We estimate the accuracy of our ablation estimates to be $10 \%$ assuming that the degree-day factor we use is correct and that the only source of error in the calculation is associated with the $1 \mathrm{~km}$ spatial resolution of the Greenland DEM used to compute the glacier area above the hinge line.

To calculate mass accumulation, we use Ohmura and Reeh (1991). Since their map was not available digitally, it was recreated on the computer (personal communication from Fahnestock and Joughin, 1996) using the original icecore data listed in their paper, interpolated on a regular grid to match best their manual interpolation. The precision of the data is difficult to establish, especially in the north where data sampling is coarse. We assume that accumulation is known with $10 \%$ accuracy based on the quality of the ice-core data $(10-20$ year records only) but the impact of the interpolation over large areas could arguably induce larger errors.

The result of the analysis is a total accumulation of $13.1 \mathrm{~km}^{3}$ ice $\mathrm{a}^{-1}$ above the hinge line, a surface ablation (or run-off) of $2.0 \mathrm{~km}^{3}$ ice $\mathrm{a}^{-1}$, and a balance flux at the hinge line of $11.1 \mathrm{~km}^{3}$ ice $\mathrm{a}^{-1}$ (Rignot and others, 1997). If the above estimates are correct, the hinge-line ice flux of Petermann
Gletscher exceeds its balance flux by $0.88 \pm 1.0 \mathrm{~km}^{3}$ ice $\mathrm{a}^{-1}$. Although the uncertainty is large, the result suggests that Petermann Gletscher loses mass to the ocean.

Joughin (personal communication, 1997) calculated an ice flux of $12.4 \mathrm{~km}^{3}$ ice ${ }^{-1}$ near the equilibrium-line elevation of Petermann Gletscher combining ERS interferometry data and ice-sounding radar (ISR profile in Figure 1). The total area in between the ISR line and the hinge line is $1056 \mathrm{~km}^{2}$. In that region, accumulation is $0.28 \mathrm{~km}^{3}$ ice a and ablation is $1.42 \mathrm{~km}^{3}$ ice $\mathrm{a}^{-1}$. The balance flux at the ISR line is therefore $12.2 \mathrm{~km}^{3}$ ice $\mathrm{a}^{-1}$, which is only $0.2 \mathrm{~km}^{3}$ ice $\mathrm{a}^{-1}$ lower than the measured ice flux. Hence, the glacier appears to be nearly in balance at the location of the ISR line. If this is true, it means that the mass deficit of Petermann Gletscher is concentrated in its lower reaches, not in the interior. Averaged over the $1056 \mathrm{~km}^{2}$ area in between the ISR profile and the hinge line, the $0.88 \pm 1.0 \mathrm{~km}^{3}$ ice a ${ }^{-1}$ mass imbalance translates into a glacier thinning of $83 \pm 94 \mathrm{~cm}$ ice $\mathrm{a}^{-1}$.

The analysis of ice fluxes is therefore suggestive of ice thinning, nearly at the same rate as that deduced from hinge-line migration. The agreement between the two methods can probably be taken as a coincidence given the large uncertainty in the ice-flux estimates. Taken differently, however, it could also mean that our estimates of accumulation and ablation for Petermann Gletscher are reasonably accurate.

This study shows that it would be misleading to conclude that Petermann Gletscher is in balance based solely on an analysis of ice fluxes in the interior. The comparison of fluxes should be done at the coast if the overall objective of the study is to measure the contribution of this part of the ice sheet to sea-level rise. To improve the quality of the balance fluxes, more accumulation and ablation data are needed in the north. The net advantage of the hinge-line migration method is that it does not depend on our knowledge of accumulation and ablation. Until more data on accumulation and ablation are collected in the north, detecting the hinge-line migration of northern outlet glaciers may be the most effective way of complementing the measurements of ice-volume changes to be conducted by laser-altimetry systems over the next decades. Of course, the technique is also applicable to Antarctic glaciers since most of the Antarctic coastline is fringed with ice shelves and floating ice tongues.

\section{GONCLUSIONS}

This study demonstrates the capability of radar interferometry to detect the hinge-line migration of outlet glaciers from space, and thereby gather precise information on its state of balance, independent of our knowledge of mass accumulation and surface ablation. In general, multiple independent mappings of the hinge line will be necessary to separate the effect of changing tide from longer-term changes in glacier thickness. Where tidal predictions are available from an ocean-tide model, however, fewer radar scenes will be needed to achieve a certain level of precision in mapping the mean sea-level hinge-line position of the glaciers. The method requires information on the glacier surface and basal slopes, which can be obtained from laser/ radar altimetry and ice-sounding radars. Radar-altimetry data are already available over the whole of Greenland 
and Antarctica to provide valuable information on surface slope.

On Petermann Gletscher, the radar-interferometry technique locates the hinge line with a precision of $30 \mathrm{~m}$ and detects hinge-line migration with a $40 \mathrm{~m}$ precision. This level of precision is unprecedented. When repeated across the entire glacier width, we find that the hinge line migrates back and forth with changing tide within a "grounding zone" a few tens of meters to a couple of hundred meters wide. This spatial variability in grounding of the glacier, probably associated with variations in bedrock topography, may be typical of most tidal glaciers. A consequence is that it would seem essential to map the hinge line across the entire glacier width rather than at a few discrete locations in order to reach reliable conclusions on its mean sea-level position as well as on its state of advance/retreat. This type of mapping exercise is probably best and only addressed by using satellite techniques.

On Petermann Gletscher, both the mass-flux method and the detection of hinge-line migration suggest ice thinning. The hinge-line migration method is more accurate but the ice-flux method is able to suggest that ice thinning is concentrated at the coast. What the techniques do not explain, however, is the cause of ice thinning on Petermann Gletscher. Over one century, a $78 \mathrm{~cm}$ ice $\mathrm{a}^{-1}$ glacier thinning should have resulted in a significant retreat of the $70 \mathrm{~m}$ thick ice-front region but this does not seem to have been the case. Hence, we hypothesize that the retreat of the hinge line of Petermann Gletscher is a recent phenomenon. Ablation conditions at the coast may have changed. Since those conditions are dominated by basal melting, it is tempting to suggest that ice-ocean interactions may have changed in the recent past in Petermann Fjord and may be elsewhere in the north.

\section{ACKNOWLEDGEMENTS}

This work was performed at the Jet Propulsion Laboratory, California Institute of Technology, under a contract with the U.S. National Aeronautics and Space Administration, Polar Program. We thank the European Space Agency for providing the ERS radar data, R. Thomas for useful discussions, P. Gogineni for providing the ice-sounding radar observations of Petermann Gletscher, W. Krabill for providing the laser-altimetry data of Petermann Gletscher, S. Ekholm for providing a digital elevation model of north Greenland, C. Werner for providing a SAR processor, and the two reviewers for providing a detailed and useful review of the manuscript.

\section{REFERENCES}

Allen, C.., S. Gogineni, B. Wohletz, K. Jezek and T. Chuah. 1997. Airborne radio echo sounding of outlet glaciers in Greenland. Int. J. Remote Sensing, 18(14), 3103-3107.
Bessels, E. 1876. Scientific results of the United States Arctic Expedition, steamer 'Polaris', C. F. Hall commanding. Vol. 1. Physical observations. Washington, DC.

Boggild, C. E., N. Reeh and H. Oerter. 1994. Modelling ablation and massbalance sensitivity to climate change of Storstrommen, northeast Greenland. Global and Planetary Change, 9(1-2), 79-90.

Braithwaite, R.J. 1995. Positive degree-day factors for ablation on the Greenland ice sheet studied by energy-balance modelling. 7. Glaciol., 41 (137), 153-160.

Braithwaite, R.J., T. Konzelmann, C. Marty and O. B. Olesen. 1998a. Errors in daily ablation measurements in North Greenland, 1993 -94, and their implications for glacier-climate studies. f. Glaciol., 44(148), $583-588$.

Braithwaite, R.J., T. Konzelmann, C. Marty and O. B. Olesen. 1998b. Reconnaissance study of glacier energy balance in North Greenland, 1993 94. 7. Glaciol. $44(147), 239-247$.

Ekholm, S. 1996. A full coverage, high resolution topographic model of Greenland computed from a variety of digital elevation data. 7 . Geophys. Res., 101 (B10), 21,961-21,972.

Goldstein, R. M., H. Engelhardt, B. Kamb and R. M. Frolich. 1993. Satellite radar interferometry for monitoring ice sheet motion: application to an Antarctic ice stream. Science, 262 (5139), 1525-1530.

Hartl, P., K. -H. Thiel, X. Wu, C. S. M. Doake and J. Sievers. 1994. Application of SAR interferometry with ERS-1 in the Antarctic. Earth Obs. Q. $43,1-4$.

Higgins, A. K. 1991. North Greenland glacier velocities and calf ice production. Polarforschung, 60 (1), 1990, 1-23.

Holdsworth, G. 1969. Flexure of a floating ice tongue. J. Glaciol., 8 (54), 385-397.

Holdsworth, G. 1977. Tidal interaction with ice shelves. Ann. Gëophys., 33 (1-2), $133-146$.

Hughes, T. 1977. West Antarctic ice streams. Rev. Geophys. Space Phys, 15 (1), 1-46.

Huybrechts, P., A. Letréguilly and N. Reeh. 1991. The Greenland ice sheet and greenhouse warming. Global and Planetary Change, 3 (4), 399-412.

Joughin, I., S. Tulaczyk, M. Fahnestock and R. Kwok. 1996. A mini-surge on the Ryder Glacier, Greenland, observed by satellite radar interferometry. Science, 274(5285), 228-230.

Koch, L. 1928. Contributions to the glaciology of North Greenland. Medd. Grenl., $65(2), 181-464$.

Koch, L. 1940. Survey of North Greenland. Medd. Gronl., 130 (1).

Konzelmann, T. and R. J. Braithwaite. 1995. Variations of ablation, albedo and energy balance at the margin of the Greenland ice sheet, Kronprins Christian Land, eastern north Greenland. F. Glaciol., 41 (137), 174- 182.

Krabill, W. B., R. H. Thomas, C. F. Martin, R. N. Swift and E. B. Frederick. 1995. Accuracy of airborne laser altimetry over the Greenland ice sheet. Int. J. Remote Sensing, 16 (7), 1211-1222.

Le Provost, C., F. Lyard, J. M. Molines, M. L. Genco and F. Rabilloud. 1998. A hydrodynamic ocean tide model improved by assimilating a satellite altimeter derived dataset. J. Geophys. Res., 103 (C3), 5513-5529.

Ohmura, A. and N. Reeh. 1991. New precipitation and accumulation maps for Greenland. f. Glaciol., 37(125), 140-148.

Reeh, N. 1991. Parameterization of melt rate and surface temperature on the Greenland ice sheet. Polarforschung, 59 (3), 1989, 113-128.

Rignot, E. 1996. Tidal motion, ice velocity and melt rate of Petermann Gletscher, Greenland, measured from radar interferometry. 7. Glaciol., 42(142), 476-485.

Rignot, E. 1998. Radar interferometry detection of hinge-line migration on Rutford Ice Stream and Carlson Inlet, Antarctica. Ann. Glaciol., 27, 25-32.

Rignot, E. J., S. P. Gogineni, W. B. Krabill and S. Ekholm. 1997. North and northeast Greenland ice discharge from satellite radar interferometry. Science, 276 (5314), 934-937.

Thomas, R. H. 1979. The dynamics of marine ice sheets. J. Glaciol., 24(90), $167-177$.

Thomas, R. H. and C. R. Bentley. 1978. A model for Holocene retreat of the West Antarctic ice sheet. Quat. Res., 10 (2), 150-170.

Vaughan, D. G. 1994. Investigating tidal flexure on an ice shelf using kinematic GPS. Ann. Glaciol., 20,372-376.

Weertman, J. 1974. Stability of the junction of an ice sheet and an ice shelf. $f$. Glaciol., $13(67), 3-11$.

Weidick, A. 1995. Greenland. U.S. Geol. Surv. Prof. Pap. 1386-C, C1-C93.

MS received 13. November 1997 and accepted in revised form 7 April 1998 